\title{
Review of Combined Magnetic and Radiometric Methods of Geophysical Survey in Nigeria
}

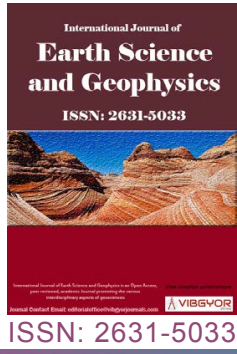

\section{Suleiman Taufiq ${ }^{1^{\star}}$, Okeke F Nneka ${ }^{2}$, Obiora N Daniel ${ }^{2}$ and Tunga U Sani ${ }^{1}$}

\author{
${ }^{1}$ Department of Science, Waziri Umaru Federal Polytechnic, Birnin Kebbi, Kebbi State, Nigeria \\ ${ }^{2}$ Department of Physics and Astronomy, University of Nigeria, Nsukka, Nigeria
}

\begin{abstract}
This paper focuses on the review of the magnetic and radiometric methods of geophysical surveys in Nigeria. It evaluates the areas/regions covered, techniques adopted vis-à-vis different software used in the investigations, the results of the investigation, and also highlighted some recommendations from articles reviewed. From the review, the southeastern part of the country revealed maximum deeper depths of $2 \mathrm{~km}, 4.85 \mathrm{~km}$ and $7 \mathrm{~km}$ while the north central part of the country revealed maximum deeper depths ranges between $0.5 \mathrm{~km}, 5.66 \mathrm{~km}, 3.24$ $\mathrm{km}$ and $2.4 \mathrm{~km}$. Also, maximum depths of $2.11 \mathrm{~km}$ and $1.5 \mathrm{~km}$ were revealed in the Northwest as against $2.8 \mathrm{~km}$ and $3.6 \mathrm{~km}$ in the southwestern part of the country. From the radiometric method, the radiogenic heat production values in most parts of Nigeria fall within the range of $0.01 \mu \mathrm{Wm}^{-3}$ to $5.43 \mu \mathrm{Wm}^{-3}$. Based on the overall results obtained from the mean concentration, internal and external hazards from the south-south and southwest of the country, it can be concluded that the soils in the areas are safe for use in constructing dwelling places in the regions. However, the coverage in this paper is by no means its entirety for the country. There is the need to carry out more of geophysical surveys on radiometric method in the northwestern part of the country, especially Sokoto Basin. It is therefore, the authors view that this paper would serve as a reference and stimulate interests in having more geophysical investigations focusing on the integration of these two methods with a view to covering some gaps in the field and pay attention to areas uncovered.
\end{abstract}

\section{Keywords}

Radiometric, Magnetic, Lineament, Radioelements, Geothermal, Radiogenic heat

\section{Introduction}

Nigeria is blessed with both natural and human resources. Among these natural resources, hydrocarbon has been of great interest and had contributed immensely to the economy of the country. Magnetic method has been deployed sufficiently in the country in the search for hydrocarbon, minerals, geothermal energy and mapping out lithology of different areas in Nigeria. In recent years, magnetic and radiometric surveys are combined in order to map out the geology of areas and carry out other geophysical surveys such as geothermal and hydrothermal alteration. The two methods have

*Corresponding author: Suleiman Taufiq, Department of Science, Waziri Umaru Federal Polytechnic, Birnin Kebbi, Kebbi State, Nigeria, Tel: 08034454194

Accepted: February 25, 2020; Published: February 27, 2020

Copyright: (c) 2020 Taufiq S, et al. This is an open-access article distributed under the terms of the Creative Commons Attribution License, which permits unrestricted use, distribution, and reproduction in any medium, provided the original author and source are credited.

Taufiq et al. Int J Earth Sci Geophys 2020, 6:032

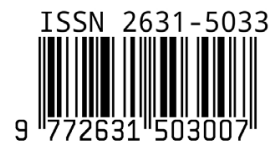

Citation: Taufiq S, Nneka OF, Daniel ON, Sani TU (2020) Review of Combined Magnetic and Radiometric Methods of Geophysical Survey in Nigeria. Int J Earth Sci Geophys 6:032 
been useful in a variety of ways, such as the provision of the third dimension to surface mapping and sampling, to improve a particular aspect of data, and integrate with other geoscience and geographical data [1]. Accordingly, the ultimate goal of using the two methods is in the production of an interpretation which highlights one or more specific problems that provide a reasonable robust and correct geological depiction. Some of these problems are; survey of hydrocarbon, investigation of magnetic and radiometric minerals, exploration of geothermal and radioactive heat, demarcation of structures and alteration under a cover of overburden or water [1].

Geoscientists, especially in Nigeria have conducted several kinds of research in different basins and basement of the country using magnetic and radiometric methods. Most of these researches dated back to the 1950s when oil and other natural resources were discovered in the country. Recently, there have been efforts to integrate these two methods (Magnetic and Radiometric) with a view to correlating the results obtained. This work, therefore, intends to compile some of the works conducted using the combined methods (magnetic and radiometric) with a view to recommending areas uncovered so that efforts can be directed judiciously to avoid repetition of the exercise, hence, accord the opportunity to concentrate on areas either yet to be covered or that need more extensive coverage.

The paper aimed at reviewing investigations that have combined magnetic and radiometric methods in Nigeria, with a view to reporting a few works carried out on magnetic and radiometric separately, areas of study vis-à-vis techniques employed therein, and, to highlight if the combined methods (magnetic and radiometric) were subjected to any form of correlation.

\section{Geology of Nigeria}

The geology of Nigeria according to Musbau [2]

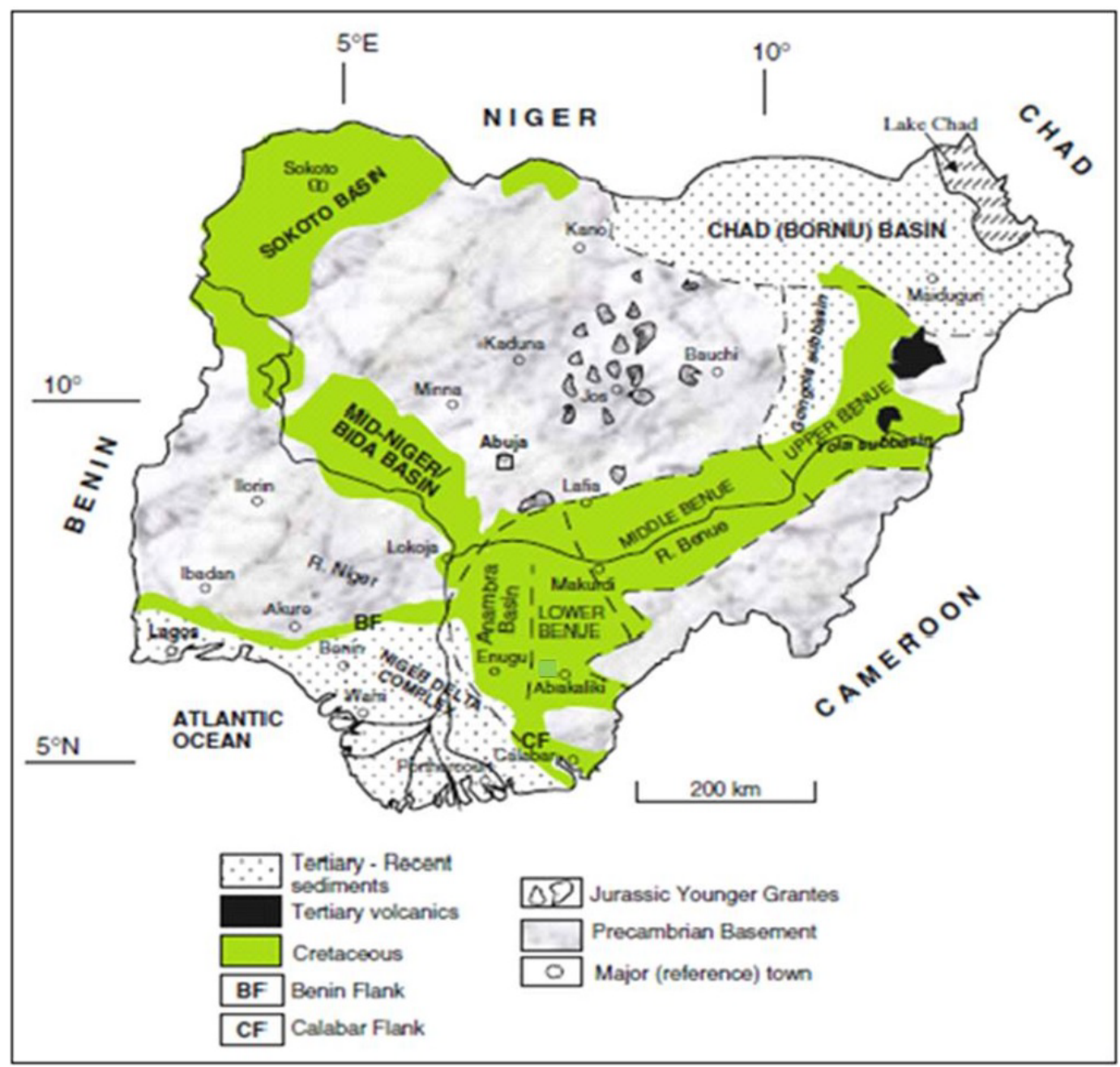

Figure 1: Geological map of Nigeria (Modified after Obaje [57]). 
is composed of Basement complex, Sedimentary series, Tertiary-Recent Volcanic rocks, and younger granites as shown in Figure 1.

The Basement complex encompasses the Migmatite-Gnesis complex, the schist belts encompasses metasedimentary and metavolcanic rocks and the Pan-African Granitoids encompasses the Older Granites and associated Charnockitic rocks. The younger granites are also found within the basement complex. The Sedimentary rocks are found in the northeast (Chad basin), northwest (Sokoto basin), Southwest, Niger, Benue Trough, Anambra, (Dahomey basin) and, the Niger Delta [3-5].

\section{Theory}

\section{Magnetic method}

A magnetic survey is a tool employed in the search for mineral bearing ore bodies or oil-bearing sedimentary structures by exploration geoscientists. Archaeologists also use it to map and locate the remains of buried structures. The magnetic survey investigates the subsurface structures based on variations in the Earth's magnetic field as a result of magnetic properties of the underlying rock [6]. Paterson and Reeves [7] concluded that the method is highly cost-effective, fast, and, widely used in terms of line length survey when compare with other geophysical surveys. The method can be performed either in the air, on land, or at sea. An airborne method is commonly employed, because of the speed of operation which makes it very attractive in the search for types of ore deposit that contain magnetic minerals. An aeromagnetic survey is carried out using magnetometer towed below or behind an aircraft flying at an altitude. The advantage of this is that larger areas of the Earth's surface are covered rapidly for regional reconnaissance. The resulting aeromagnetic map shows the spatial distribution and relative abundance of magnetic minerals. According to Burger, et al. [8], aeromagnetic surveys are widely used to aid in the production of geological maps and are commonly used during mineral exploration. In academics, the method has been useful in regional investigations of large-scale crustal features, although the sources of major magnetic anomalies tend to be restricted to rocks of the basic or ultra-basic composition.
The concept underlying magnetic prospecting is the existence of a magnetic dipole within the rocks constituting the earth [9]. Mathematically, magnetic force expression, $\mathrm{F}$ between two magnetic poles of strength $P_{1}$ and $P_{2}[10]$ is given by:

$$
F_{m}=\frac{p_{1} p_{2}}{\mu r^{2}}
$$

Where $P_{1}$ and $P_{2}$ are dipoles, $r$ is the distance between $P_{1}$ and $P_{2}$ (in meters), $\mu$ is the free space permeability.

The above Coulomb's equation is the basic underlying principle of magnetic prospecting. Magnetic poles, $P_{1}$ or $P_{2}$ which exerts force per unit pole strength can be expressed as:

$$
H=\frac{P}{r^{2}}
$$

Where $H$ is the strength of the magnetic field.

Magnetic materials positioned within a magnetic field will acquire magnetic force and will experience magnetic induction. Due to the inducing field, one can measure the strength of the magnetic field known as the intensity of magnetization, $J_{i}$, induced on the material and this is expressed as:

$$
J_{i}=k T
$$

Where $J$ is the magnetization, $k$ is the susceptibility of the magnetic material and $T$ is the inducing field.

For low external magnetic fields (e.g., the earth), the degree in which the body is magnetized is determined by its magnetic susceptibility, $k$, and is defined as:

$$
M=k H
$$

Where $M$ is magnetic polarization, $k$ is magnetic susceptibility and $H$ is Magnetic field intensity.

The measurement of the total magnetic field, (which includes the external magnetic field and the magnetization) is called the Magnetic Induction $(B)$ and is written as

$$
B=\mu_{0}(1+k) H
$$

Where, $\mu_{o}$ is the magnetic permeability of free space. The unit of $B$ is teslas, which is generally too 
large a number for applied magnetic work, so gammas ( $10^{-9}$ teslas) are more commonly used. $B$ is a vector quantity and in most magnetic work today, the amplitude of $B$ is measured and it is called the total magnetic field.

\section{Radiometric method}

Radioactivity is simply the process in which an unstable atom becomes stable through the process of decay of its nucleus [11]. Radiometrics or Gamma ray spectrometry is a geophysical method used to estimate the concentrations of the radio-elements; potassium, uranium and thorium by measuring the gamma rays emitted by the radioactive isotopes of these elements during radioactive decay. Potassium $\left({ }^{40} \mathrm{~K}\right)$, Uranium $\left({ }^{235} \mathrm{U},{ }^{238} \mathrm{U}\right)$ and Thorium $\left({ }^{232} \mathrm{Th}\right)$ are the three principal natural radioactive elements of the earth's crust.

Gamma radiation is one of the electromagnetic spectra that travel at the speed of light (c) and have a discreet energy (E), wavelength $(\lambda)$ and frequency (f). These are related by:

$$
E=h f=\frac{h c}{\lambda}
$$

Decay chain series: The decay chain refers to the radioactive decay of different discrete radioactive decay products as a chained series of transformations. The law of radioactivity decay states that the reduction in the quantity of atoms of unstable nuclei with time is expressed as [12]:

$$
N_{t}=N_{0} e^{-\lambda t}
$$

Where $N_{t}$ is the quantity of atoms after decay with time $t(\mathrm{~s}), N_{0}$ is the initial quantity of atoms and $\lambda$ is the decay constant of the unstable nuclei $\left(s^{-1}\right)$.

The half-life $T_{1 / 2}(\mathrm{~s})$ of an element is simply defined as the time taken for $N_{0}$ to decrease by half.

$$
T_{1 / 2}=\frac{0.693}{\lambda}
$$

The $\lambda$ multiplied by $N$ gives the activity ( $\mathrm{Bq}$ ) of the unstable nuclei. Disintegration of unstable nucleus does not depend on additional physical factors [12].

Previous Works on Magnetic and Radiometric Methods of Geophysical Survey
Arinze, et al. [13] analyzed aeromagnetic anomalies and structural lineaments for mineral and hydrocarbon exploration in Ikom and its environs southeastern Nigeria. The study lies between latitudes $5^{\circ} 45^{\prime} 00^{\prime \prime}$ and $6^{\circ} 45^{\prime} 00 \mathrm{~N}$, and longitudes $8^{\circ} 30$ ' $00^{\prime \prime}$ and $9^{\circ} \mathrm{O} 0^{\prime} \mathrm{OOE}$ in Cross-river state in southern Nigeria. The investigation was aimed at analyzing the aeromagnetic data of Ikom and its environs in Cross-River State, Nigeria in order to delineate the structural lineaments according to their spatial and directional attributes as well as define the depth to magnetic causative bodies. The results revealed depth for the deeper causative sources ranged between $0.83 \mathrm{~km}-3.5 \mathrm{~km}$ with a magnetic intensity range of $-30 \mathrm{nT}$ to $-220 \mathrm{nT}$ while the superficial sources had a range of $0.2 \mathrm{~km}-0.75 \mathrm{~km}$ and a magnetic intensity that vary from $-10 \mathrm{nT}$ to $20 \mathrm{nT}$. The authors indicated that the deeper magnetic sources are attributed to the underlying pre-Cambrian basement complex rocks and intra-basement structures such as fractures and faults whereas the superficial sources are due to basement intrusives as well as ore-bearing veins present in the overlying Cretaceous rocks. The shallow basement depth and prevalence of intrusives and linear structures are indications of an area of good mineral prospects but unfavorable for hydrocarbon formation.

Ugwu, et al. [9] subjected aeromagnetic data of Mmaku and its environs, Southeast Nigeria for evaluation of hydrocarbon potential. The study area is Enugu state and parts of Anambra state, Southeast Nigeria which falls within the Lower Benue Trough, latitude $6^{\circ} 00^{\prime}-6^{\circ} 30^{\prime} \mathrm{N}$ and longitude $7^{\circ} 00^{\prime}-7^{\circ} 30^{\prime} \mathrm{E}$, and used map sheet 301. The use of MS Excel, WingLink, OriginPro8 and Surfer10 software were employed by the authors for the presentation and interpretation of data. Consequently, they classified the area into three groups, thus, high magnetic anomalies, medium and low magnetic anomalies. They assumed that the magnetic basement around Mmaku area is characterized by low magnetic anomalies to medium magnetic anomalies, while high magnetic anomalies are found in most part of Udi plateau. This is an indication that the rock is richer in iron compared with the surrounding rocks and could possibly be a pluton of moderate extent and of felsic magmatic origin. The authors indicated a dominant lineament trend of NE-SW and an average depth within the area was estimated to be 7 $\mathrm{km}$. Accordingly, the authors felt this depth thickness is low compared to the sedimentary thickness 
in the Niger-Delta region which is found to be above $10 \mathrm{~km}$, however, they concluded that the $7 \mathrm{~km}$ depth is still sufficient for hydrocarbon generation.

Emmanuel, et al. [14] interpreted aeromagnetic data of Mambilla Plateau in North Central Part of Nigeria for Potential Minerals. This was achieved by employing standard Euler deconvolution and forward and inverse modeling techniques. The study area (Mambilla plateau) according to the authors is located between latitude $5^{\circ}$ to $7^{\circ} \mathrm{N}$ and longitude $10^{\circ}$ to $11^{\circ} \mathrm{E}$ with a total land mass of $3,765.2 \mathrm{~km}^{2}$ [15]. Their study area falls under the Sardauna local government area in Taraba State, Nigeria, which is bounded in the southern, eastern and almost half of its western part by Cameroon. The work was aimed at estimating the depth to the basement, determining the magnetic susceptibility and type of mineralization predominant in the area, hence, the authors employed Oasis Montaj and Potent $Q$ software in the analysis. The 3D Euler deconvolution depth estimation for structural index ( $\mathrm{SI}=0.3$ and $0.5)$ ranges from $-213.9 m$ to $-2112.0 m$ and -239.9 $m$ to $-2374.9 \mathrm{~m}$, respectively were observed. Depth estimate of forward and inverse modeling for profiles P1, P2, P3, and P4 are $2372 \mathrm{~m}, 2537 \mathrm{~m}, 1621$ $\mathrm{m}$, and $1586 \mathrm{~m}$, with susceptibility values of 0.0754 , $0.0251,0.0028$, and 0.001 respectively were also observed. The authors concluded that the bodies causing the anomaly are typical of igneous rocks; basalt and olivine, intermediate igneous rock; granites, and rocks mineral (quartz).

Oha, et al. [16] interpreted high resolution aeromagnetic data over southern Benue Trough, southeastern Nigeria.

The study area lies between the latitude of 5.30' - 7.00' $\mathrm{N}$ and longitude 7.30' - 9.00'E. The investigation was aimed at estimate the depth of magnetic sources and to map the distribution and orientation of subsurface structural features. Different enhancements such as first and second vertical derivatives, horizontal gradients and analytic signal were applied to the data upon reducing the total magnetic intensity to equator. Similarly, the authors also employed 3D standard Euler deconvolution, source parameter imaging techniques and 2D modeling for depth estimation. Results from the 3D Euler deconvolution and SPI revealed maximum depth of 4.40 and $4.85 \mathrm{~km}$ respectively. The $2 \mathrm{D}$ modeling of magnetic anomalies in the study area reveal the existence of deep seated faults which may have controlled the emplacement of intrusive bodies in the basin. They concluded that the area possesses high potential for large accumulation of base metal mineralization.

Obiora, et al. [17] interpreted the aeromagnetic data of Nsukka and its environs qualitatively and quantitatively. They aimed at determining the sedimentary thickness, magnetic susceptibilities and types of mineralization prevalent in their study area, hence, they employed the techniques of the Standard Euler deconvolution, Source Parameter Imaging (SPI) and Forward and Inverse modelling in the quantitative interpretation with the aid of Oasis montaj 6.4.2 and PotentQ 4.10.07 software in the analysis of data. Consequently, forward and inverse modelling estimated depths of profiles 1, 2, 3, 4 and 5 were 1644, 2285, 1972, 2193 and $1200 \mathrm{~m}$ respectively, with respective susceptibility values of $0.0031,0.0073,1.4493,0.0069$ and 0.0016 which is an indication of dominance of iron-rich minerals like hematite, pyrrhotite, limonites, and pyrite and also forms lateritic caps on sandstones. They also observed that shallow depths of the magnetic source are good potential water reservoirs for Nsukka and its environs, while depths of $1.6 \mathrm{~km}$ to $3.1 \mathrm{~km}$ show adequately sedimentary thickness suitable for hydrocarbon accumulations.

Ofor and Udensi [18] determined the heat flow of Sokoto basin using spectral analysis of aeromagnetic data. The study area lies between longitudes $3^{\circ} \mathrm{E}$ and $8^{\circ} \mathrm{E}$ and latitudes $10^{\circ} \mathrm{N}$ and $14^{\circ} \mathrm{N}$. The aim of their work was to estimate the thickness of the basin, determine heat flow and geothermal gradient that could be of use for geothermal energy. The result suggested a centroid depth of $6.35 \mathrm{~km}$ to $13.05 \mathrm{~km}$, while the deepest basement was found at the northeastern portion toward the Republic of Niger and varies between $0.61 \mathrm{~km}$ and $1.54 \mathrm{~km}$. The results further revealed a curie point depth of between $11.36 \mathrm{~km}$ to $22.30 \mathrm{~km}$, geothermal gradient values between $26.18{ }^{\circ} \mathrm{C} / \mathrm{km}$ to $44.62{ }^{\circ} \mathrm{C} / \mathrm{km}$, and heat flow values from $52.36 \mathrm{~mW} / \mathrm{m}^{2}$ to 98.57 $\mathrm{mW} / \mathrm{m}^{2}$. The maximum heat flow value was found around Tambuwal Local Government Area in Sokoto State. Values between $80 \mathrm{~mW} / \mathrm{m}^{2}$ and $100 \mathrm{~mW} /$ $\mathrm{m}^{2}$ are considered as good geothermal sources since the average heat flow in the normal continental region is about $60 \mathrm{~mW} / \mathrm{m}^{2}$. They concluded that areas with high heat values may be good geothermal sources and recommended those areas for further geophysical investigations. 
Few other authors who used aeromagnetic data for estimation of depth are Emmanuel, et al. [19] who interpreted aeromagnetic anomalies over Maiduguri-Dikwa depression, Chad Basin, Nigeria, in order to establish its main shallow crustal structural features. Spectral analysis and 2D modelling of four profiles selected from the residual anomaly map, provided depth to basement of $2.82,3.41$, 2.41 , and $2.56 \mathrm{~km}$. They also found out that the area is intensely fractured, with major fractures trending in the NE-SW direction. Olowofela, et al. [20] estimated magnetic basement depths beneath the Abeokuta Area, South West Nigeria from Aeromagnetic data using power spectrum. Their results indicated that the shallow source depth is $0.467 \mathrm{~km}$ and the deeper sources depth is $2.797 \mathrm{~km}$. They assumed that the shallow depth of $0.467 \mathrm{~km}$ might probably be due to intrusive within the sediment while deeper depth of $2.797 \mathrm{~km}$ is attributed to underlying basement. Shehu, et al. [21] assessed geothermal potential of Sokoto Basin using spectral centroid analysis of high-resolution aeromagnetic data. Their results indicated a range of the depths to the top of magnetic sources from 0.59 to $2.11 \mathrm{~km}$ with an average value of $1.22 \mathrm{~km}$ and the centroid depth range from 6.27 to $14.30 \mathrm{~km}$ with an average of $9.90 \mathrm{~km}$, while the curie point depth (CPD) range from 11.13 to $27.83 \mathrm{~km}$ with an average value of $18.57 \mathrm{~km}$. Kassidy and Nur [22] analyzed aeromagnetic data over Mutum-Biyu and environs, in Taraba northeast Nigeria. The deeper sources which represent the basement vary between 661 $\mathrm{m}$ near Jalingo to $2722 \mathrm{~m}$ at Bantaji town, while the shallower magnetic sources range between $37 \mathrm{~m}$ at Gurumpawa to 590 m close to Gidan Shanu, and are attributed to near surface intrusion. Ikumbur, et al. [23] used spectral analysis for the interpretation of aeromagnetic data over some parts of the Southern Bida Basin, Northcentral, Nigeria. The results they obtained revealed two depth sources, the deeper sources, which ranges from $2.81 \mathrm{~km}$ to $3.24 \mathrm{~km}$, and the shallower sources, which ranges from $0.45 \mathrm{~km}$ to $1.49 \mathrm{~km}$. Nwosu [24] also used the spectral analysis to re-evaluate the magnetic basement depth over some parts of the middle Benue trough Nigeria, using the high resolution aeromagnetic data in order to consider for hydrocarbon potential in the area. The deeper source depth ranges from $2.33 \mathrm{~km}$ to $5.66 \mathrm{~km}$ with an average depth of $3.65 \mathrm{~km}$, which is considered as the magnetic basement depth, while the shallower sources depth ranges from $0.07 \mathrm{~km}$ to $0.42 \mathrm{~km}$ with an average depth of $0.21 \mathrm{~km}$. Megwara and Udensi [1] carried out structural analysis over parts of southern Bida basin and the surrounding basement rocks using aeromagnetic data for the purposes of highlighting linear structures, and deduce the effects of such features on the tectonic events in their survey area. Their results using Euler deconvolution method show that depth to magnetic sources ranges from $0.01 \mathrm{~km}$ to $0.51 \mathrm{~km}$ with an average value of 0.128 $\mathrm{km}$.

On the radiometric survey, Kuforijimi and Christopher [25] carried out an assessment of Aero-radiometric data of Southern Anambra Basin for the prospect of Radiogenic Heat Production. Their study area is bounded by latitudes $7^{\circ}$ and $9^{\circ} \mathrm{N}$ and longitudes $6^{\circ}$ and $7^{\circ} \mathrm{E}$ and covers an area of approximately $33708 \mathrm{Km}^{2}$. The work was aimed at having a comprehensive geothermal location in the area and to know the potential effects of geothermal energy and radiogenic heat production in Nigeria. To achieve this, twelve aeromagnetic maps numbered 268-271, 287-290 \& 301-304 were fed into Oasis Montaj" to process each radio-element. The three elements were combined to form a total count map and rock unit boundaries were clearly separated by geo-referencing and digitizing the geological map of the study area in order to show each rock unit present and the concentration of radioelements. The authors analyzed the radiogenic heat using the calculation of ratios from the three radio-elements: Potassium (\%), Uranium (ppm), and Thorium (ppm) using a similar method of Salem, et al. [26] and Megwara, et al. [1]. Similarly, the radiogenic heat values were also calculated from the energy released from the Alpha, Beta and Gamma decay of rocks [27] with the aid of an empirical equation by Rybach [28]. Consequently, thirteen rock units (Unidentified Basement Complex, Granite, Asu River Group, Eze Aku Group, Awgu Ndeaboh Shale Group, Asata Nkporo Group, Lower Coal Measures, False bedded Sandstones, Bende Ameki Group, Imo Clay -Shale Group, Alluvium, Basic and Intermediate Intrusions and Basalt Trachyte Rhyolite) were identified and were further assigned for calculation of the radiogenic heat production based on the concentrations of the three radioelements within each rock unit. The results of the analysis of the radiogenic heat production range between $0.01 \mu \mathrm{Wm}^{-3}$ - and $5.43 \mu \mathrm{Wm}^{-3}$, recorded the highest heat production at the sedimentary rocks (Shale) 
with a value up to $5.43 \mu \mathrm{Wm}^{-3}$ around Aimeke and Ogobia. The authors concluded that Aimeke and Ogobia areas are hotspots because of the high values of radiogenic heat production, which is above $4 \mu \mathrm{Wm}^{-3}$ for high radiogenic heat production [29].

Akpan, et al. [30] investigated ground radiometric of Akpabuyo, Nigeria, for natural radiation levels and their radiological effects. Their study area according to the authors is located between Latitudes $4^{\circ} 55^{\prime}$ and $4^{\circ} 57^{\prime} \mathrm{N}$ and Longitudes $8^{\circ} 29^{\prime}$ and $8^{\circ} 31^{\prime} \mathrm{E}$ in Akpabuyo Local Government Area (LGA), Cross River State, Nigeria. The aim of the investigation was to assess the magnitude and spatial distribution of activity concentrations from primordial radionuclides, radiological hazard assessment and their associated risk to both humans and environment, and to find out the suitability of the soils in the area for constructing dwellings places. Potable GRS-2 model of a Pico Envirotech spectrometer was the instrument used by the authors in determining the concentration of $U, T h$, and $K$ in the study area. Interestingly, the authors reported that the activity mean concentration of ${ }^{238} \mathrm{U},{ }^{232} \mathrm{Th}$, and ${ }^{40} \mathrm{~K}$ which varies with spatial distribution of soil texture, lithology, land use and topography were 34.67 $\mathrm{Bqkg}^{-1}, 38.59 \mathrm{Bqkg}^{-1}$ and $114.66 \mathrm{Bqkg}^{-1}$ respectively are slightly higher than the World averages (30 $\mathrm{Bqkg}^{-1}$ for $\mathrm{U}$ and $39 \mathrm{Bqkg}^{-1}$ for Th) except for ${ }^{40} \mathrm{~K}$ which was found to be less than the World average of $400 \mathrm{Bqkg}^{-1}$. Also, the result of external hazard indices varied between $0.11 \mathrm{~Bq} \mathrm{~kg}^{-1}$ and 0.46 $\mathrm{Bq} \mathrm{kg}^{-1}$ (average of $0.27 \mathrm{~Bq} \mathrm{~kg}^{-1}$ ) and internal hazard indices varied between $0.14 \mathrm{~Bq} \mathrm{~kg}{ }^{-1}$ and $0.72 \mathrm{~Bq}$ $\mathrm{kg}^{-1}$ (average of $0.36 \mathrm{~Bq} \mathrm{~kg}^{-1}$ ). Impliedly, the results of internal and external hazard indices are below the $1 \mathrm{~Bq} \mathrm{~kg}^{-1}$ standard requirement for materials to be safe for use in building constructions. Absorbed dose rate varies from $19.37 \mathrm{nGy} \mathrm{h}^{-1}$ to $76.72 \mathrm{nGy}$ $\mathrm{h}^{-1}$ (average of $44.11 \mathrm{nGy} \mathrm{h}^{-1}$ ), indoor annual effective dose rate varies from 0.10 to $0.38 \mathrm{mSv} \mathrm{vr}^{-1}$ (average of $0.22 \mathrm{mSv} \mathrm{yr}^{-1}$ ) and outdoor annual effective dose rates varies from 0.02 to $0.09 \mathrm{mSv} \mathrm{yr}^{-1}$ (mean of $0.05 \mathrm{mSv} \mathrm{yr}^{-1}$ ). The mean absorbed dose rate is nearly equal to the world average of $44 \mathrm{nGy} \mathrm{hr}{ }^{-1}$, but both means of the indoor and outdoor annual effective doses are below the $0.50 \mathrm{mSv} \mathrm{yr}^{-1}$ limit set for materials to be safe. Based on the overall results obtained from the work, the authors came to the conclusion that the soils in the study area are safe for use in constructing dwelling places and recommended periodic monitoring of the radionu- clides and radioisotopes of the area.

Shehu and Nwankwo [31] investigated Radiogenic Heat Production in the crust using high-resolution Aeroradiometric data in parts of Sokoto Basin, Nigeria. The research was aimed at identifying clean and renewable energy sources that can be a better alternative to burning fossil fuels. The work was achieved by calculating Radiogenic Heat Production from radioelements concentration of geothermal resources. Consequently, the result showed a radiogenic heat production which ranged from 0.07 to $5.48 \mu \mathrm{Wm}^{-3}$ with an average value of $1.07 \mu \mathrm{Wm}^{-3}$. Using Rybach average of 2.25 $\mu \mathrm{Wm}^{-3}$ for rocks and sedimentary formation as the standard, the authors asserted that Kalmalo, Sokoto, Argungu, Dange, Birnin Kebbi and Giru with radiogenic heat production values of $3.62 \mu \mathrm{Wm}^{-3}$, $3.10 \mu \mathrm{Wm}^{-3}, 2.82 \mu \mathrm{Wm}^{-3}, 5.48 \mu \mathrm{Wm}^{-3}, 2.70 \mu \mathrm{Wm}^{-}$ ${ }^{3}$ and $2.67 \mu \mathrm{Wm}^{-3}$ respectively, have values found to be due to high heat production of ${ }^{238} \mathrm{U}$. These are suggestive of anomalous geothermal conditions, and therefore, may be good areas for geothermal exploration which can be tapped as an alternative to fossil fuel-based energy in Nigeria. They also opined that some of the areas with the radiometric anomaly, are lithologically consistent with limestone, granite, and shale which are known to have the highest concentration of ${ }^{40} \mathrm{~K},{ }^{238} \mathrm{U}$ and ${ }^{232} \mathrm{Th}$.

Coker, et al. [32] who embarked on a radiometric investigation in order to determine the terrestrial gamma radiation level of Sagamu and Abeokuta areas, Southwest. The authors revealed results for on-ground basement complex and sedimentary terrain that vary between $32.79 \mathrm{nGy} / \mathrm{hr}$ to 42.58 $\mathrm{nGy} / \mathrm{hr}$ and $23.79 \mathrm{nGy} / \mathrm{hr}$ to $23.83 \mathrm{nGy} / \mathrm{hr}$ respectively. Similarly, above the ground for basement and sedimentary terrain was found between 26.71 $\mathrm{nGy} / \mathrm{hr}$ to $38.25 \mathrm{nGy} / \mathrm{hr}$ and $20.37 \mathrm{nGy} / \mathrm{hr}$ to 21.32 $\mathrm{nGy} / \mathrm{hr}$ respectively. They also found that the thorium and uranium content of rocks increases with acidity, with the highest concentrations found in basement complex and lowest concentrations found in sedimentary terrain. Coker, et al. [33] also used application of radiometric survey in delineating between sedimentary basin and basement complex of Sagamu and Abeokuta, Southwestern Nigeria. The result revealed values of $72 \mathrm{Bqkq}^{-1} \pm 48$ $\mathrm{Bqkq}^{-1}, 35 \mathrm{Bqkq}^{-1} \pm 20 \mathrm{Bqkq}^{-1}, 43 \mathrm{Bqkq}^{-1} \pm 26 \mathrm{Bqkq}^{-}$ ${ }^{1}$ for ${ }^{40} \mathrm{~K},{ }^{226} \mathrm{Ra}$ and ${ }^{232}$ Thorium respectively in sedimentary terrain. While average values of $80 \mathrm{Bqkq}^{-1}$ 
$\pm 46 \mathrm{Bqkq}^{-1}, 44 \mathrm{Bqkq}^{-1} \pm 18 \mathrm{Bqkq}^{-1}$ and $53 \mathrm{Bqkq}^{-1} \pm$ $25 \mathrm{Bqkq}^{-1}$ for ${ }^{40} \mathrm{~K},{ }^{226} \mathrm{Ra}$ and ${ }^{232} \mathrm{Th}$ respectively in the basement complex. These results indicated higher concentration of ${ }^{40} \mathrm{~K}$ than ${ }^{226} \mathrm{Ra}$ and ${ }^{232} \mathrm{Th}$ both in the sedimentary terrain and basement complex, hence, they concluded to have succeeded in delineating between the two terrains on the bases that, in the basement complex, granites contain high concentrations of uranium, thorium and potassium.

\section{Previous works on combined magnetic and ra- diometric methods}

Ademila [34] carried out integrated geophysical methods for subsurface characterization and assessment of health hazard in the basement complex of Southwestern Nigeria. The author used aeromagnetic data, aero radiometric data and complemented the work with a ground radiometric survey. Ikole Sheet number $\mathbf{2 4 5}$ was used as the study area for the investigation, with the coordinates of latitudes $7^{\circ} 30 \mathrm{~N}$ and $8^{\circ} 00 \mathrm{~N}$ and longitudes $5^{\circ} 30 \mathrm{E}$ and $6^{\circ} 00 \mathrm{E}$. Gamma Ray Spectrometer was employed in acquiring ground radioelements data in the area along eight traverses, taken on outcrops of charnockite, grey-gneiss, granite-gneiss, and granite using a spreading length of $100 \mathrm{~m}$ of $5 \mathrm{~m}$ spacing between station positions. The author adopted filtering and reduction of aeromagnetic data, reduced the data to magnetic equator using reduction to equator filter. Residual - regional separation was processed thereafter and upward continuation was applied. The author divided the residual map into four quadrants and was windowed out for the determination of each radial average power spectrum used for depth to the top of magnetic sources estimation. For the radiometric data, the gridded data were fed into Oasis MontajTM Software for appropriate filtering so as to enhance signals attributed to important subsurface signatures and natural radioactivity. After the normalization of the respective radioelements to cancel the effect of potassium which is the most crustal abundant radioactive elements from dominating and overriding other radioelements, a ternary map was produced using Oasis Montaj. Finally, the mean values for Absorbed Dose Rate (D), Annual Effective Dose Equivalent (AEDE), and Internal and External Hazard Indices were computed using standard equations from the ground radiometric data for the eight traverses. UNSCEAR [35] formula was employed in estimating gamma radiation dose, $A E D E$ received outdoor by a member of the public was calculated from the absorbed dose rate using a dose conversion factor of $0.7 \mathrm{~Sv} / \mathrm{Gy}$ and occupancy factor for outdoor and indoor was 0.2 and 0.8 respectively [36]. The external $\left(\mathrm{H}_{\mathrm{ex}}\right)$ and internal $\left(\mathrm{H}_{\text {in }}\right)$ radiation hazard indices were calculated respectively due to natural radionuclides of ${ }^{238} \mathrm{U},{ }^{232} \mathrm{Th}$ and ${ }^{40} \mathrm{~K}$. The external and internal indices were estimated using the expression of Ramasamy, et al. [37]. Similarly, the elemental concentrations of ${ }^{238} \mathrm{U}$ (in ppm), ${ }^{232} \mathrm{Th}$ (in ppm) and ${ }^{40} \mathrm{~K}$ (in \%) were also calculated from measured activity concentrations of ${ }^{238} \mathrm{U},{ }^{232} \mathrm{Th}$ and ${ }^{40} \mathrm{~K}$ in Bqkg ${ }^{1}$ using the conversion factors recommended by the IAEA [12]. Consequently, from the magnetic perspective, the author revealed N-S structural trends and regional lineament trending NE-SW directions. Spectral depth estimation of $3.6 \mathrm{~km}$, different range of magnetic intensities and susceptibilities were also discovered. From the radiometric, AEDE, Absorbed Dose Rate, the External and Internal Hazard Indices have estimated values that are below the world standard limit. Therefore, the author concluded that her study areas pose no risk to humans inhabiting the area or in nearby areas.

Ejepu, et al. [38] carried out an integration of geosciences prospecting for gold mineralization in Kwakuti, Northcentral Nigeria. The authors deployed aeromagnetic and aeroradiometric in surface geological mapping, processed and analyzed total magnetic field intensity data using Oasis Montaj software and X-rayed fluorescence analysis of soil sample respectively. According to the authors, their study area is bounded by Latitudes $9.362500^{\circ} \mathrm{N}$ to $9.387500^{\circ} \mathrm{N}$ and Longitudes $6.920833^{\circ} \mathrm{E}$ to $6.945833^{\circ} \mathrm{E}$ in Northern Nigeria. The investigation was aimed at lithologic and structural analysis of remote sensing images, surface geological mapping, pitting and sample collection. Soil samples were collected in the neighbourhood of stream channels by the authors and analysis was carried out with the aid of X-Ray Fluorescence. The geological mapping exercise was done using a topographic map on a scale of 12,500 captured data were tied to Universal Transverse Mercator (UTM), WGS 84 zone $32 \mathrm{~N}$ system. ArcGIS software was employed in gridding of the data using the minimum curvature gridding method [39]. For the magnetic data, the data was reduced to the magnetic equator, where first vertical, total horizontal and tilt derivatives analytical signal, source parameter imaging were all applied to the RTE. Consequently, the RTE map revealed a 
magnetic field intensity values which range from $40 \mathrm{nT}$ to $67 \mathrm{nT}$ and were the characteristics of the rocks in the area. They reported that very low magnetic regions coincided with high elevations regions and the regions are underlain with migmatites and dykes. While areas of moderate elevations are associated with high magnetic anomalous corresponding to schistose rocks. Contact zones recorded low magnetic anomaly and opined that it is an indication of demagnetization of magnetite minerals to hematite minerals with a low magnetic response as a result of hydrothermal fluid flow through fractures and faults [40]. They concluded that the prospective fault-bounded contact between the migmatites and the schists may potentially host mineralization in the area.

Kuforijimi and Christopher [25] correlated and mapped geothermal and radioactive heat production from the Anambra Basin, Nigeria. They studied area of latitudes $6^{\circ} 00^{\prime} \mathrm{N}$ and $7^{\circ} 30^{\prime} \mathrm{N}$ and longitudes $6^{\circ} 30^{\prime} \mathrm{E}$ and $9^{\circ} 00^{\prime} \mathrm{E}$. The authors utilized twelve aeromagnetic sheets numbering 268-271, 287-290 and 301-304 for their study. The aeromagnetic data were reduced to the equator using a Butterworth lowpass filter. Subsequently, the polynomial filtering method of regional-residual was employed, where the residual data was Fourier transformed and the area was subdivided into thirty-five (35) overlapping sections for the purpose of spectral analysis [41]. The Curie point depth was calculated and the value of heat flow was obtained from Fourier's law $[42,43]$. The geothermal gradient was estimated as the ratio of Curie-point temperature to Curie-point depth ${ }^{\circ} \mathrm{C} \mathrm{km}^{-1}$. In their study, $2.5 \mathrm{Wm}^{-1}{ }^{\circ} \mathrm{C}^{-1}$ [44] was taken as an average value of thermal conductivity, because Shale is the predominant lithology in the area. Also, the values of radioactive heat were calculated from the energy released from the Alpha, Beta and Gamma decay of rocks [27] using an empirical equation by Rybach [45]. The results from the spectral analysis indicated that deeper sources have depths ranging from $8.03 \mathrm{~km}$ to $19.85 \mathrm{~km}$ while the shallow sources have depths ranging from $0.59 \mathrm{~km}$ to $3.86 \mathrm{~km}$. The values of Curie-point depth ranged from $14.64 \mathrm{~km}$ to $38.62 \mathrm{~km}$, and the values of geothermal heat flow varied from $99.02 \mathrm{mWm}^{-2}$ in the upper part of Enugu and Agwu, to very low value ( $37.54 \mathrm{mWm}^{-2}$ ) around Aimeke in the lower part around Iboko. The values of thorium, uranium and potassium abundance ranged from $4.3 \mathrm{ppm}$ to 24.6 ppm, $0.6 \mathrm{ppm}$ to $6.8 \mathrm{ppm}$, and $0.0 \%$ to $1.3 \%$ respec- tively. The authors went further and correlated ternary map and total magnetic map. They indicated that there was high thorium concentration around Aimeke, Abakaliki, Ekuaro, Nsukka, Mbasere, Ogobia, and Iboko which corresponded with high total magnetic intensity anomalies in the same areas, while low thorium concentration observed around Amagunze, Ankpa, Akpanya, Emandak, and Igumale corresponded with low magnetic intensity anomalies in the same areas. For uranium, high uranium concentration observed around Aimeke and Ogobia corresponded with high total magnetic intensity anomalies in the same area, while low uranium concentration observed around Ankpa and Akpanya corresponded with low magnetic intensity anomalies in the same area. For potassium, high potassium concentration observed in Aimeke, Iboko, Ishieke, Ogobia, and Nde corresponded with high total magnetic intensity anomalies, while low thorium concentration observed in Ankpa, Akpanya, Ejule, Nsukka, and Ngwo corresponded with low magnetic intensity anomalies. From the radiometric heat flow map of the area, the authors indicated that Aimeke and Ogobia indicated high concentration values of both uranium, thorium and potassium. Hence, they concluded that these specific areas are considered appropriate for geothermal resource. The authors, therefore, recommended a comprehensive ground radiometric and magnetic surveys with soil test at Aimeke and Ogobia which are considered as hotspots.

Falade \& Adepelumi [46] Combined High-Resolution Aeromagnetic and Radiometric data in the mapping of uranium mineralization and tectonic settings in Northeastern Nigeria. Their aim was to identify the potential zones of uranium deposition in the area. It was reported by the authors that the area is bounded by latitude $11^{\circ} 30-12^{\circ} 00 \mathrm{~N}$ and longitude $10^{\circ} 00-10^{\circ} 30 \mathrm{E}$. The data were gridded at 100 $\mathrm{m}$ spacing using the method of minimum curvature gridding. The High-Resolution Aeromagnetic Data was processed to accentuate anomalies of interest using reduction-to-equator and upward continuation filters. Thereafter, spectral analysis and Source Parameter Imaging (SPI) techniques were employed for the depths to the basement estimation from the data, while the structural lineament map of the study area was inferred from the superposition of the Horizontal Gradient Magnitude (HGM), Analytical Signal Amplitude (ASA), First Vertical Derivative (FVD) and 3D Euler solutions of the HRAD. Magne- 
tic forward modeling of two profiles ( $\mathrm{P}-\mathrm{P}^{\prime}$ and $\mathrm{T}-\mathrm{T}^{\prime}$ ) taken across the suspected uranium-rich zones was carried out to provide 2D model representations of the basement blocks beneath the zones. The equivalent Uranium (eU) and equivalent Thorium (eTh) distribution maps of the radiometric data were processed to obtain the eU2/eTh, eU/eTh and eU (eTh/3.5) ratio maps which were used to determine the concentrations and remobilization of uranium. From the magnetic perspective, the authors obtained the following results: (i) Depths to the basement which ranged between 150 and 1941 m; (ii) Lineament structures which dip vertically, northeasterly, southwesterly, northwesterly and southeasterly; (iii) Several structures that trend ENE - WSW, NE SW, E - W, NNE - SSW, WNW - ESE and NW - SE; among which the ENE - WSW and NE - SW trends dominate and (iv) The uplifts and depressions on the map of the basement morphology coincide with the basement complex and the sedimentary terrains of the area respectively. Results from the eU2/ eTh, eU/eTh and eU (eTh/3.5) ratio analyses revealed that uranium ores in the area were possibly remobilized epigenetically from the granitic rocks and were later deposited into sedimentary rocks (Bima formation), and in fault and fracture zones to form uranium veinlet in the Basement Complex terrains. The Burashika Group (Bongna Hills) and Wawa areas show vein type deposition, while the Anatectic migmatite in the northeastern region and the uranium-rich Bima formations show both fault and contact types of deposition. The authors concluded that the area contained deposits of uranium ore which are likely to be found in the Bima Hill, Shinga, Bima sandstones of Wade, Wuyo, Teli, Dali, Barkan, Gasi, Bryel, Deba, Kunkun, Boragara, and Gberundi localities. Also, the Anatectic migmatite can be found at Kubuku, Whada and Hyama; Bongna hills and agglomerates around Burashika, Kawaba and Galu.

Eze, et al. [47] investigated geological and structural interpretation of possible mineralization zones of part of Anambra basin and Southern Benue Trough using high resolution aeromagnetic and radiometric data. Their study area covers the Southern Benue trough, upper Anambra basin and Nigeria Basement complex bounded it at the Southeastern portion of the area. The area is bounded by longitude $7.30^{\circ} \mathrm{E}$ to $9.00^{\circ} \mathrm{E}$ and latitude $6.00^{\circ} \mathrm{N}$ to $7.30^{\circ} \mathrm{N}$. Analytic signal, first and second vertical derivatives, horizontal derivative and tilt derivative were employed in delineating mag- netic lineaments, edges, lithological boundaries, and contact zones within the area were processed. The ternary image which was generated from Radiometric data using oasis Montaj software highlighted the lithology of the area. It was observed that the anomalies on the TMI map are characterized by smooth contours and low magnetic relief while the surrounding platform area shows steep gradients and high relief. The authors identified conspicuous lineaments at the central portion of the area around Igumale, and northwest of Benta, which is an area within the Albian Asu River group of Southern Benue Trough. Equally observed is the lowest amplitude which ranged from 0.02 to 0.009 cycles, that they are regions with magnetic rock intruding into sedimentary formations at greater depths. The likely areas with high concentrations of mineral deposits (intrusive areas) correlate with high analytical signal amplitude. They observed a remarkable increase in the potassium concentrations westwards into the Benue trough compared to the depletion of potassium in the Anambra basin. Interestingly, the authors correlated and found out that the areas with a high concentration of mineral deposits coincided with high analytical signal amplitude.

Cyril, et al. [48] carried out an integrated method using magnetic, radiometric and geochemical Survey of Quarry Sites in Ondo State, Southwestern, Nigeria. They studied Elegbeka, Ayegunle and Supare areas within Latitude $7^{\circ} 00 \mathrm{~N}-7^{\circ} 30 \mathrm{~N}$ and Longitude $5^{\circ} 30 \mathrm{E}-5^{\circ} 60 \mathrm{E}$ within the basement complex of $\mathrm{Ni}-$ geria and underlain by Southwestern Nigeria's Precambrian basement complex rocks. They conducted ground magnetic and radiometric investigations on foot using GSM-19T Proton Precision Magnetometer and portable handheld detector Gamma Ray Spectrometer respectively, with Garmin Global Positioning System (GPS) navigational equipment for real-time measurements. The authors carefully established a base station near the respective quarry site where the magnetometer was continuously returned to correct for diurnal variations of earth magnetic field and other sources of external origin. Consequently, two magnetic and radiometric measurements were taken by the authors per station with a traverse length of $1000 \mathrm{~m}$ of spacing 5 $\mathrm{m}$ each for total traverses of Elegbeka Quarry (4), Ayegunle Quarry (4) and Supare (3) respectively. A total of 11 readings were taken at the base stations together with readings of the time for the magnetic 
survey. The mean of the magnetic and radiometric measurements was adopted as the raw data for each observed station and acquired data was drift corrected. The authors also collected twenty topsoil samples (Elegbeka quarry (7), Ayegunle quarry (7) and Supare quarry (6)) from their study area at a depth of about $5-10 \mathrm{~cm}$. Oasis MontajTM was used for both magnetic and radiometric data processing, dataset and images production for interpretation. While Energy Dispersive X-ray Fluorescence (EDXRF) spectrometry was used in analyzing all the soil samples. The quantitative analysis of samples was carried out using the XRF-FP Quantitative Analysis Software package. Consequently, TMI, FFT, average radial power spectrum, Euler plots and its $3 D$ for the depth estimates were produced for respective quarry site investigated. The results of the $\mathrm{K}(\%), \mathrm{U}(\mathrm{ppm})$ and Th (ppm) with their Coordinates for the respective quarry in the area were imported into Oasis MontajTM to produce the Ternary images. There was also the usage of Microsoft Excel in producing the profiles $\mathrm{K}(\%), \mathrm{U}(\mathrm{ppm}), \mathrm{Th}(\mathrm{ppm})$ and the concentration of the major elements, heavy metals and trace elements bar plot respectively for the three quarry sites investigated in the area for clearer pictorial representation of the level of radiations and chemical concentrations in the area. Results obtained indicated depth estimates between $100 \mathrm{~m}$ to $800 \mathrm{~m}$, lows, and highs magnetic images with amplitude variation between $3326.79 \mathrm{nT}$ and 1284.61 $\mathrm{nT}$, lineament structures with infilled geological materials (lows) and closeness basement (highs). The authors attributed the relatively low and high values of magnetic intensities to the perceived variation in the magnetic properties that correlate to the accident intrusive and metamorphosed igneous rocks in the area. Radioelements results indicated mean concentration of $4.8 \mathrm{ppm}$ for $\mathrm{U}, 16.3 \mathrm{ppm}$ for Th and $2.85 \%$ for K. XRF for geochemical assessment revealed the impact of the quarrying activities and showed the abundance of the major elements to be in the order of $\mathrm{Fe}>\mathrm{Ti}>\mathrm{K}>\mathrm{Ca}$, heavy metals: $\mathrm{Zn}>\mathrm{Cu}$ $>\mathrm{Pb}>\mathrm{As}$, and trace elements $\mathrm{Mo}>\mathrm{Mn}>\mathrm{Zr}>\mathrm{V}>\mathrm{Ce}$ $>\mathrm{Cr}$ respectively. They concluded that the analyzed soil samples from their study area were below the tolerance level when compared with international standard and the area is considered safe to humans for agricultural practices.

Bassey and Barka [49] carried out lithology and structural mapping in Song Area, Northeastern Nigeria using aeromagnetic and ground radiome- tric data. They studied Song and its environs with an area extent of about $118.7 \mathrm{~km}^{2}$, situated along Yola-Gombi Road in northeastern Nigeria. The area is defined by longitude $12^{\circ} 35 \mathrm{E}-12^{\circ} 40 \mathrm{E}$ and latitude $9^{\circ} 45 \mathrm{~N}-9^{\circ} 52 \mathrm{~N}$. They aimed at just carrying out lithology and mapping out the area structurally. In order to achieve this, the author made use of surfer 9 software in countering the digitized data, separated residual anomaly from the TMI using statistical analysis, countored the residual value at an interval of $10 \mathrm{nT}$. Radiometric data was also acquired by Gamma-Scout ${ }^{\circledR}$ based on data acquisition and field measures presented by Bassey, et al. [50] and countered using surfer 9 . They compared residual magnetic map and radiometric lineament map produced on a similar basis and observed E-W lineament and NE-SW lineament on both maps. They assumed that some of the lineaments have been earlier observed $[50,51]$ and mapped as faults and dykes. They observed further that, NW-SE lineaments were found at the Northwest margin of the magnetic lineament map, while on the radiometric map, the Northwest lineaments were found at the Northwest, Northeast, the West and to the South. They indicated that the NW lineaments at the north-west corner are attributed to mapped shear zones, those at the north-east are spatially related/or coincident with the emplacements of granite gneiss and basalt in Murkuchi area respectively. The NW trending lineaments to the west are well correlated with the emplacement direction of the granite outcrops found between Jabbure and Wuro Yakubu. Its trend is also consistent with and correlates well with the shear zone and strike-slip fault found between Wuro Yakubu and Argurvila. This shear/ fault zone has been geophysically proven to extend through Wuro Yakubu to the southeast [49]. By implication the two NW lineaments found to the south is an extension of these shear/fault zone. N-S lineaments are not found on the magnetic map but on the radiometric map. Its presence in the northwest is interpreted as the emplacement direction of basalt northwest of Song Town. The two other $\mathrm{N}-\mathrm{S}$ lineaments found to the east are well correlated with the general flow direction of Mayo Song and the emplacement direction of the granite pluton at Wuro Yalde.

Megwara, et al. [1] determined geothermal heat flow and radioactive heat characterization of Bida basin and surrounding basement using aeromagnetic and aero-radiometric data. The authors repor- 
ted that the area is bounded by Longitude $4.5^{\circ} \mathrm{E}$ to $8.0^{\circ} \mathrm{E}$ and Latitude $8.0^{\circ} \mathrm{N}$ to $9.0^{\circ} \mathrm{N}$, with an estimated area of $33,275 \mathrm{~km}^{2}$, which consist of basal Lokoja formation, overlaying by the Patti formation and capped by the Agbaja formation. Eleven (11) aeromagnetic map sheets with numbers 202-208 and 225-228 and 11 radiometric sheets covering the area were used in the investigation. The magnetic data were processed by subjecting it to regional - residual separation using Robust Polynomial fitting method, followed by a fractal-depth method, which was applied to 22 fractal subsections covering their study area. The Residual magnetic field data for each section was downwardly continued. Depth to top and bottom of magnetic sources were obtained from a technique developed by Maus, et al. [52], modified by Bouligand, et al. [53]. Geothermal heat flow was calculated from the description of Mujgan, et al. [54]. Radioactive heat production on the other side was estimated from radiometric data based on the description of Salem and Fairhead [27]. Results from their study indicated that the values of depth-to-top ranged between 0.022 $\mathrm{km}$ and $3.88 \mathrm{~km}$ with an average value of $1.299 \mathrm{~km}$, while depth-to-bottom of magnetic sources ranged between $8.364 \mathrm{~km}$ to $15.094 \mathrm{~km}$, with an average value of $11.837 \mathrm{~km}$. The geothermal heat flow values lie between $69.167 \mathrm{mWm}^{-2}$ and 124.821 $\mathrm{mWm}^{-2}$ (average value of $90.959 \mathrm{mWm}^{-2}$ ). Also, the values of radioactive heat lie between $0.91 \mu \mathrm{W} / \mathrm{m}^{3}$ and $4.53 \mu \mathrm{W} / \mathrm{m}^{3}$ (average value of $2.28 \mu \mathrm{W} / \mathrm{m}^{3}$ ). The radioactive heat map showed high radioactive heat values at Lafiagi, Kuje, Katakwa, Isanlu, Karu, and Ndegi, while low radioactive heat values were observed at Baro, Koton Karifi, Pategi, Share, Keffi, Share, and Garaku. From the ternary map of the result, there was a high concentration of Thorium around Isanlu, Kuje and Low concentration was predominant around Garaku and Ndegi. Potassium showed high concentration around Isanlu, Share, Aiyegunle, Lafiagi, Ndegi, Keffi and low concentration were prevalent around Gulu, Katakwa and Koton Karifi. Uranium showed high concentration around Isanlu, Gulu, Katakwa and low concentration was prevalent around Pategi, Aiyegunle, and Lafiagi. From the correlation of radioactive heat and geothermal heat flow maps done by the authors, it was deduced that there was high radioactive heat value $\left(3.75 \mu \mathrm{W} / \mathrm{m}^{3}\right)$ at Kalawa which corresponded with high geothermal heat flow value (102.213 $\mathrm{mW} / \mathrm{m}^{2}$ ) at the same point.
Bassey and Ishaku [55] integrated magnetic and radiometric survey in part of the Modibbo Adama University of Technology, Yola over areas of exposed/outcropping ferruginous sandstone belonging to Bima Formation of the Yola Rift Sedimentary Basin. The aim of the research was to see if the magnetic/radiometric surveys could be used to effectively map such deposits which are locally quarried and used for construction purposes. The authors reported that the area of their study lies in the north part of the Modibbo University of Technology, Yola, between longitudes $12^{\circ} 29.620$ and $12^{\circ} 30.159 \mathrm{E}$, and latitudes $9^{\circ} 21.100$ and $9^{\circ} 21.663 \mathrm{~N}$. The area is part of the Yola Rift Basin, an arm of the Benue Trough. They surveyed 1000 by $850 \mathrm{~m}$ i.e. $850,000 \mathrm{~m}^{2}$, stretches $1 \mathrm{~km}$ in the north-south and $850 \mathrm{~m}$ in the east-west direction. The survey was carried out along six profiles with a separation of $150 \mathrm{~m}$ (along the $\mathrm{N}$-S direction perpendicular to E-W Yola Trough), with the exception of the last two traverses toward the west boundary which had a separation of $100 \mathrm{~m}$ because of a new building under construction that interfered with the regular $(150 \mathrm{~m})$ separation. Station spacing was $50 \mathrm{~m}$, thus each profile had 20 stations. Station location was achieved by use of $100 \mathrm{~m}$ measuring tape and

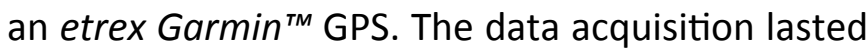
for about one week. At each station, both magnetic and radiometric readings were taken simultaneously. The proton precession magnetometer and the Gamma Scout were employed for the magnetic and radiometric field measurements respectively. Only the gamma radiation was measured. A geological compass was used to define the baseline of the survey area along the E-W direction. Time recording for possible diurnal correction was done with an electronic stop-watch. Since relatively few and short traverses were surveyed, each day's survey was done in about two hours or less. Hence station reoccupation for diurnal correction was considered unnecessary. The anomalies encountered in this work are distinct though they are $<500$ gammas. Radiometric data at each station was observed over an interval of 3 minutes, this was later averaged to get the cpm. The magnetic and radiometric data were separately contoured using surfer 8 software. A ground check on the anomalies was done using the GPS to locate their positions on the ground. From the field observations carried out by the authors, they observed an inverse relationship between the ferruginous and the feldspar contents 
of the sandstone and deduced that areas of high magnetic anomalies are sometimes coincident with areas of low radiometry. Equally, the ground follow-up of mapped anomalies showed that some magnetic anomalies coincide with ferruginous outcrops, while the rest of the magnetic anomalies are attributed to sub-cropping ferruginous sandstones.

\section{Summary of Review}

Geophysical surveys on magnetic and radiometric works across Nigeria have been reviewed. An effort was geared towards assessing various researches on these methods from the geo-scientific perspectives. The magnetic method has been deployed sufficiently in Nigeria to estimate depth thickness, which will, in turn, serve as an indicator for hydrocarbon potential either in commercial quantities or otherwise. The method has also been used for the detection of minerals, especially in the basement complex/areas. Recently, geoscientists in the country have gone further to estimate heat flow and geothermal gradient from the magnetic method leading to geothermal energy that could serve as an alternative to fusil fuel burning. Different techniques in analyzing data (spectral analysis, Euler deconvolution, forward and inverse modeling, SPI) are now widely used with good results obtained.

From the radiometric survey (ground and airborne), it could be deduced that this method has been useful in mapping out the geology of an area, for geothermal exploration, radiological hazard assessment, determination of the concentration of radioelements, delineating between sedimentary and basement complex, etc. This method has been deployed sufficiently in the Southern parts of the country and some part of Northcentral and Northeast. Rybach $[28,56]$ methods of calculating the concentration of radioelements appear to be dominant in all the investigations. Results obtained especially where the method was used for natural radiation level and radiological effects showed that areas are safe and pose no risk to human and the environment. There is therefore the need to conduct similar research in the Northwest with a view to finding out the radiation level and radiological effects to both humans and the environment.

From the work of Shehu and Nwankwo [31] which can be said to be the only known radiometric investigation done in the Sokoto basin so far, the authors were able to identify some areas which they classified as hotspot for geothermal energy. Kuforijimi and Christopher [25] and Megwara, et al. [1] integrated magnetic and radiometric methods and found some areas with high geothermal gradient coincided with high radiogenic production are recommended those areas for geothermal energy. Eze, et al. [47] correlated areas with high analytical signal amplitude with the high concentration of radioelements, while Bassey and Barka [49] whose interest was to carry out lithology and structural mapping correlated so many lineaments maps of magnetic and radiometric as highlighted in this work. The work of Ademila [34] whose study area was just a part in Ondo state corroborated with the work of Cyril, et al. [48] who covered the entire Ondo State in terms of safety of the radioelements.

\section{Conclusion}

Conclusively, from the literature reviewed, Nigerian geological terrain is grouped into two settings: the sedimentary basin and the basement complex. Both sedimentary and basement complex have received adequate geophysical attention using magnetic method with few investigations on radiometric method, and combination of magnetic and radiometric method. It is therefore recommended that the Nigerian government should focus on exploration of minerals and geothermal as an alternative to oil and hydropower respectively. There is need to embark on more geophysical surveys, especially combined magnetic and radiometric in Sokoto basin as a follow up to earlier works in the basin. There is also the need to embark on radiometric survey for assessing natural radiation levels and their radiological effects in the region where such research has not been adequately conducted.

\section{References}

1. Megwara JU, Emmanuel EU, Peter IO, Mohammed AD, Kolawole ML (2013) Geothermal and Radioactive heat studies of parts of Southern Bida Basin, Nigeria and the surrounding basement rocks. International Journal of Basic and Applied Sciences 2: 125-139.

2. Musbau AF (2014) Geology and mineral resources of Oyo State, South Western Nigeria. Journal of Scientific Research \& Reports 3: 2718-2731.

3. McCurry P (1976) The geology of the Precambrian to lower paleaozoic rocks of Northern Nigeria: A review. In: Kogbe CA, Geology of Nigeria. Elizabethan 
Pub Co, Lagos, 18-40.

4. Peters SW (1991) Precambrian geology of Africa. Lecture Notes on Fourth Sciences, Springer Berlin, Heidelberg, Germany, 40.

5. Rahman MA (1976) Review of the basement geology of Southern Nigeria. In: Kogbe CA, Geology of Nigeria. Elizabethan Pub Co, Lagos, 45-58.

6. Campbell WH (2003) Introduction to geomagnetic fields. ( $\left.2^{\text {nd }} e d n\right)$, Cambridge University press, London.

7. Paterson NR, Reeves CV (1985) Applications of gravity and magnetic: The state-of-the-art in 1985. Geophysics 50: 2558-2594.

8. Burger RH, Sheehan AF, Jones $\mathrm{CH}$ (2006) Introduction to Applied Geophysics. WW Norton, 600.

9. Ugwu SA, Nwankwo CN, Umeanoh DC (2017) Investigation of subsurface structures for the evaluation of hydrocarbon potential using Aeromagnetic Data from Mmaku and its Environs, South-East Nigeria. Journal of Scientific and Engineering Research 4: 152-164.

10.Ariffin KS (2012) Geophysical prospecting. Earth Science Department, University of Melbourne, Australia.

11. Kearey P, Brooks M, Hill I (2002) An introduction to geophysical Exploration. ( $3^{\text {rd }}$ edn), TJ international, England, 2-160.

12.IAEA (2003) Guidelines for radioelement mapping using gamma ray spectrometry data, Vienna, Austria.

13.Arinze JI, Emedo OC, Ngwaka AC (2018) Analysis of aeromagnetic anomalies and structural lineaments for mineral and hydrocarbon exploration in Ikom and its environs southeastern Nigeria. Journal of African Earth Sciences 151: 274-285

14.Emmanuel Al, John AY, Immaculate UI (2018) Investigation of Mambila Plateau in North Central Part of Nigeria for potential minerals using aeromagnetic method. IOSR Journal of Applied Geology and Geophysics 6: 10-22.

15.Tukur AL, Adebayo AA, Galtima A (2005) The land and people of the Mambilla Plateau. Heinemann Educational books, Nigeria.

16.Oha IA, Onuoha KM, Nwegbu AN, Abba AU (2016) Interpretation of high resolution aeromagnetic data over southern Benue Trough, southeastern Nigeria. J Earth Syst Sci 125: 369-385.

17.Obiora DN, Ossai MN, Okwoli E (2015) A case study of aeromagnetic data interpretation of Nsukka area, Enugu state, Nigeria, for hydrocarbon exploration. International Journal of Physical Sciences 10: 503-
519.

18.Ofor NP, Udensi EE (2014) Determination of the heat flow in the Sokoto Basin, Nigeria using spectral analysis of aeromagnetic data. Journal of Natural Sciences Research 4: 83-93.

19.Emmanuel KA, Ajana GO, Augustine IC, Leonard NO (2011) The interpretation of the aeromagnetic anomalies over Maiduguri-Dikwa depression, Chad Basin Nigeria : A structural view. Archives of Applied Science Research 3: 499-508.

20.Olowofela JA, Akinyemi OD, Idowu OA, Olurin OT, Ganiyu SA (2012) Estimation of magnetic basement depths beneath the Abeokuta Area, South West Nigeria from aeromagnetic data using power spectrum. Asian Journal of Earth Sciences 5: 70-78.

21.Shehu AT, Olatunji S, Lawal TO (2016) Assessment of geothermal potential of Sokoto Basin, Northwestern Nigeria using spectral centroid analysis of high-resolution aeromagnetic (HRAM) data. Journal of Science, Technology, Mathematics and Education 12: 27-36.

22.Kassidy S, Nur A (2012) Analysis of Aeromagnetic data over Mutum-Biyu and its environs, Northeastern, Nigeria. Research Journal in Engineering and Applied Sciences 1: 142-148.

23.Ikumbur EB, Onwuemesi AG, Anakwuba EK, Chinwoko Al, Usman AO, et al. (2013) Spectral analysis of aeromagnetic data over part of the southern Bida basin, West-central Nigeria. International Journal of Fundamental Physical Sciences 3: 27-31.

24.Nwosu OB (2013) Spectral Re-Evaluation of the magnetic basement depth over parts of Middle Benue Trough Nigeria, Using HRAM. International Journal of Scientific and Technology research 2: 35-41.

25. Kuforijimi O, Christopher A (2017) Assessment of aero-radiometric data of Southern Anambra Basin for the prospect of radiogenic heat production. J Appl Sci Environ Manage 21: 743-748.

26.Salem A, Abouelhoda E, Alaa A, Atef I, Sachio E, et al. (2005) Mapping radioactive heat production from airborne spectral gamma-ray data of Gebel Duwi Area, Egypt. Proceedings World Geothermal Congress, Antalya, Turkey, 24-29.

27.Salem A, Fairhead D (2011) Geothermal reconnaissance of Gebel Duwi area, Northern Red Sea, Egypt using airborne magnetic and spectral gamma ray data. Getech 1-22.

28. Rybach L (1976) Radioactive heat production in rocks and its relation to other Petrophysical parameters. Pure and Appl Geophysics 114: 309-318. 
29. Alistair TM, Thomas LH, Paul LY, David CW, Alan JC (2014) Gamma-ray spectrometry in geothermal exploration: State of the art techniques. Energies 7: 4757-4780.

30.Akpan AE, Paul ND, Uwah EJ (2016) Ground radiometric investigation of natural radiation levels and their radiological effects in Akpabuyo, Nigeria. Journal of African Earth Sciences 123: 185-192.

31.Shehu AT, Nwankwo LI (2015) Radiogenic heat production in the crust using high-resolution aeroradiometric (HRAR) data in parts of Sokoto Basin, Nigeria. Journal of Science, Technology, Mathematics, and Education 11: 120-130.

32.Coker JO, Mustapha AO, Makinde V, Adesodun JK (2014) Radiometric survey to determine the terrestrial gamma radiation levels: A case study of Sagamu and Abeokuta, South Western Nigeria. Int J Pure Appl Sci Technol 21: 31-38.

33. Coker JO, Mustapha AO, Makinde V, Adesodun JK (2013) Application of radiometric surveys to delineate between sedimentary terrain and basement complex: A case study of Sagamu and Abeokuta, South Western Nigeria. Journal of Natural Sciences Research 3: 13-16.

34.Ademila O (2018) Integrated geophysical methods for subsurface characterisation and health IOP Conf Ser: Earth Environ Sci 173.

35.UNSCEAR (2000) United Nations Scientific Committee on the Effects of Atomic Radiation Sources, effects and risks of ionizing radiation. Report to the general assembly, annexes B: Exposure from natural radiation sources. New York, 678-679.

36.Veiga RG, Sanches N, Anjos RM, Macario K, Bastos J, et al. (2006) Measurement of natural radioactivity in Brazilian beach sands. Radiation Measurements 41: 189-196.

37. Ramasamy V, Suresh G, Meenakshisundaram V, Gajendran V (2009) Evaluation of natural radionuclide content in river sediments and excess lifetime cancer risk due to gamma radioactivity. Research Journal of Environmental and Earth Sciences 1: 6-10.

38.Ejepu JS, Unuevho Cl, Ako TA, Abdullahi S (2018) Integrated geosciences prospecting for gold mineralization in Kwakuti, North-Central Nigeria. Journal of Geology and Mining Research 10: 81-94.

39. Briggs IC (1974) Machine contouring using minimum curvature. Geophysics 39: 39-48.

40.Wilford J, Bierwirth P, Craig M (1997) Application of airborne gamma-ray spectrometry in soil/regolith mapping and applied geomorphology. Journal of
Australian Geology and Geophysics 17: 201-216.

41.Udensi EE, Osazuwa IB (2004) Spectral determination of depths to magnetic rocks under the Nupe Basin, Nigeria. Nigerian Association of Petroleum Explorationists (NAPE) Bull 17: 22-27.

42.Tanaka A, Okubo Y, Matsubayashi O (1999) Curie point depth based on spectrum analysis of the magnetic anomaly data in East and Southeast Asia. Tectonophysics 306: 461-470.

43.Tanaka A, Ishikawa Y (2005) Crustal thermal regime inferred from magnetic anomaly data and its relationship to seismogenic layer thickness: The Japanese islands case study. Phys Earth Planet Inter 152: 257-266.

44. Reiter MA, Jessop AM (1985) Estimates of terrestrial heat flow in offshore Eastern Canada. Can J Earth Sci 22: 1503-1517.

45. Rybach L, Schwarz GF (1995) Ground gamma radiation maps: Processing of airborne, laboratory, and in situ spectrometry data. First Break 13: 97-104.

46. Falade HA, Adepelumi AA (2017) Combined high-resolution aeromagnetic and radiometric mapping of uranium mineralization and tectonic settings in Northeastern Nigeria. Acta Geophysica 65: 10431068.

47.Eze MO, Mamah LI, Madu AJC, Leonard O (2017) Geological and structural interpretation of possible mineralization zones of part of Anambra basin and Southern Benue Trough using airborne geophysical data. International Journal of Research in Engineering and Applied Sciences (IJREAS) 7: 70-80.

48.Cyril CO, Adedibu SA (2016) Magnetic, radiometric and geochemical survey of quarry sites in Ondo State, Southwestern, Nigeria. International Basic and Applied Research Journal 2: 16-30.

49. Barka J, Bassey NE (2015) Gradio-magnetic and resistivity exploration for groundwater in Wuro Yakubu Song Area, Hawal Basement Complex, Northeast Nigeria. Jour Geog Environ and Earth Sc International 2: 37-45.

50.Bassey NE, Kaigama U, Oluwasegun A (2013) Radiometric mapping of Song Area and Environs, Hawal basement complex, North East Nigeria. International Jour Sc Tech (UK) 2: 692-699.

51.Barka J, Bassey NE, Tabale RP (2013) Magnetic Anomalies and Structures in Song, Hawal Basement Complex Northeastern Nigeria. Journal of Environmental Sciences and Resource Management 5: 27-41.

52. Maus S, Gordon D, Fairhead D (1997) Curie tempera- 
ture depth estimation using a self-similar magnetization model. Geophysical Journal International 129: 163-168.

53.Bouligand C, Jonathan M, Glen G, Blakely RJ (2009) Mapping Curie temperature depth in the western United States with a fractal model for crustal magnetization. Journal of Geophysical Research 114: 1-25.

54.Müjgan S, Oya P, Ilknur K (2005) Determination of the curie point depth and heat flow from magsat data of Western Anatolia. Journal of Balkan Geophysical Society 8: 149-160.
55. Bassey NE, Ishaku JM (2012) Conjunctive use of magnetic and radiometric surveys for mapping of ferruginous sandstone horizons in Yola area, Nigeria. Journal of Earth Sciences and Geotechnical Engineering 2: 39-51.

56. Rybach L, Hokrick R, Eugester W (1988) Vertical earth heat probe measurement and prospects in Switzerland. Communication and Proceedings 1: 167-372.

57.Obaje NG (2009) Geology and mineral resources of Nigeria. Lecture notes in earth sciences. Bhattacharji S, Neugebauer HJ, Reitner J, Stuwe K, Springer, New York. 